\title{
Modelling Velocity Distributions and River Bed Changes Using Computer Code SSIIM below Sills Stabilizing the Riverbed
}

\author{
Mateusz Hämmerling ${ }^{1}$, Natalia Walczak ${ }^{1}$, Agata Nowak ${ }^{2}$, \\ Robert Mazur ${ }^{2 *}$, Joanna Chmist ${ }^{1}$ \\ 'Department of Hydraulic and Sanitary Engineering, Faculty of Land Reclamation and Environmental Engineering, \\ Poznań University of Life Sciences, Poznań, Poland \\ ${ }^{2}$ Department of Geoinformation Photogrammetry and Remote Sensing of Environment and Department \\ of Environmental Management and Protection, AGH University of Science and Technology, \\ Kraków, Poland
}

Received: 3 May 2017

Accepted: 11 February 2018

\begin{abstract}
The aim of this study was risk assessment regarding the local scours below sills that stabilize the Warta riverbed below Jeziorsko Reservoir. The studied river sills were constructed due to the reduction of riverbed erosion that took place downstream behind the dam reservoir. The research area embraced two reaches: in the vicinity, sills No. $3(\mathrm{~km} \mathrm{480+902)} \mathrm{and} \mathrm{No.} 4(\mathrm{~km} \mathrm{479+225)}$ were built in order to reduce local and general riverbed erosion resulting from the construction of the reservoir. The current article presents the methodology of the conducted field research and a short description of the applied mathematical model SSIM (a three-dimensional numerical model for simulating sediment movements in water intakes with multiblock options). Based on field geometry measurements of the local scour holes, the distribution of water velocity, and the water levels in the period 20062010, calculations of velocity distributions at the sill have been carried out using SSIIM software. The computer simulations have shown that the calculated water velocity profiles did not differ significantly from the measured ones.
\end{abstract}

Keywords: mathematical modelling, SSIIM, riverbed erosion, velocity distribution, riverbed processes

\section{Introduction}

The construction of Jeziorsko Reservoir on the Warta River in 1986 interfered with the continuity of sediment transport, resulting in an intensification of riverbed

*e-mail: mazur@agh.edu.pl erosion downstream from the reservoir [1]. Additional factors increasing erosion of the riverbed and river banks downstream from reservoirs are the increased kinetic energy and turbulence of the water flow that occurs primarily in the local scour downstream of a weir or sill. The first sills, PR. -1 and PR. -2 , were located in $240 \mathrm{~m}$ and $360 \mathrm{~m}$ after the dam and were designed in order to prevent riverbed erosion behind the dam and 
the formation of local scour downstream of the weir. Both sills fulfill their functions properly in the vicinity of hydrotechnical constructions, but they haven't stop longitudinal erosion downstream of the Warta River.

In 2005, in order to reduce the effects of local and longitudinal erosion, stone mattresses were used to build two other sills, No. $3(\mathrm{~km} \mathrm{480+902)}$ and

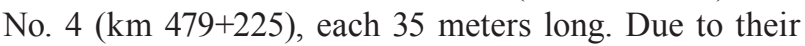
simple construction and the danger of loss of stability in periods of flood water in the river, the sills were further analyzed, including measurements of changes in the riverbed bottom geometry.

Their construction reduced erosion processes downstream of the reservoir on the section from the weir to sill No. 4 [2]. However, just below the stabilizing sills local scour holes were formed, which may pose a threat to the sills' stability, and indirectly to the entire dam.

To determine the degree of risk for the sills by erosion, we must determine the kinematics of the water flow below each sill, the type of substrate in the river bottom, and its erodibility.

This article deals with the kinematics of the water flow below. Sills No. 3 and No. 4 were selected for the ability to obtain records since their construction.

Numerical codes are commonly used to simulate both water flow in open channels (for example, HECRAS package and SPRUNER [3]) and seepage from reservoirs, (e.g., HYDRUS software [4]). The literature contains many examples of velocity distribution measurement methods for modelling them using various mathematical tools [5]. Urbański and Siwicki [6] presented a comparison of velocity distributions and turbulence intensity measured on a weir laboratory model with results obtained using Fluent software.

Cellino and Graff [7] presented velocity distributions describing the flow of water over bedforms. Analysis of velocity distributions recorded by Cellino and Graff [6] show that the formation of the recirculation zone below the bed forms dunes that are similar to those generated in local scour holes.

Termini and Sammartano [8] described the development of the local scour below the horizontal solid apron. The authors analysed the flow area and its turbulence characteristics [9]. They also analysed the transverse velocity distribution at various distances from the initial cross-section. Termini (2011) [10] performed numerical calculations using Fluent software, with a 2-D velocity model of water distributions and bottom shear stress. The results obtained were compared with those experimentally recorded by other researchers. Radecki-Pawlik and Radecki-Pawlik [11] analyzes several classic formulas for calculating the beginning of bedload transport. Sarahet et al. [12] successfully used the Flow Tracker AVD to determine the structure of flow turbulence in local scour.

Local scour processes downstream from a submerged sluice gate were discussed by Oliveto et al. and D'Agostino and Ferro [13, 14], who proposed a suitable physical model due to the particle size on a local channel.

The results of laboratory models are described in articles by Espa and Sybilla [15], who conducted experimental research on the process of local scour in the non-cohesive soil. The authors presented the changes (variation) in geometrical parameters of local scour over time and measured the velocity distribution in the research area. They also compared the simulation model from the Schoklitsch and Shalash equations to the physical model from the recorded maximal depth of local erosion.

Chen et al. [16] analysed their laboratory experiments and assumed that many parameters affect local scour lengths, such as dam geometry, particle size in sediment composition, Froude number, and the critical velocities of water flow for initial movements of bed material.

Research by Bennet and Alonso and Shen et al. $[17,18]$ revealed that sheer velocity gradient, turbulent shear stress, and the bottom pressure gradient have the greatest influence on riverbed erosion associated with local scour formation.

Barrios-Piña et al., [19] in numerical research, verified the applicability of a simpler turbulence model than the commonly used k- $\varepsilon$ model to predict mean flow through vegetation.

Salem-Said et al. [20] presented results and twophase (water and air) flow in a $6 \mathrm{~m}^{3}$ model of Dorr-Oliver flotation cell, which was an air-forced mechanically stirred machine.

Kaiglová et al., Elhakeem and Sattar, and Dysarz et al. [21-23] used different sediment transport and hydrodynamic mathematical models to describe the potential and limitations of various channel schematizations. Plesiński et al. [24] are presenting the grain size analysis of gravels, which are basically the bed load of Ponikiewka Stream.

The results of an experimental study by Tregnaghi et al. [25] confirmed that the area of scour is highly dependent on bed particle size, the relative roughness of the solid aprons, the second critical depth, and the size of vortexes.

Zahiri et al. [26] showed that the roughness of the end of solid aprons strongly affects the local scour area. They analysed records of measurements of geometric characteristics of local erosion for different initial conditions.

Jafari et al. [27] applied a mathematical model (SSIIM) in depth modelling of the local scour formed under a bridge pier. A comparison of the results of the two models (experimental and numerical) showed that they were highly compatible.

Many publications present numerical models calculated based on the Zinke et al., Olsen, and Hämmerling et al. mathematical model [28-30]. 

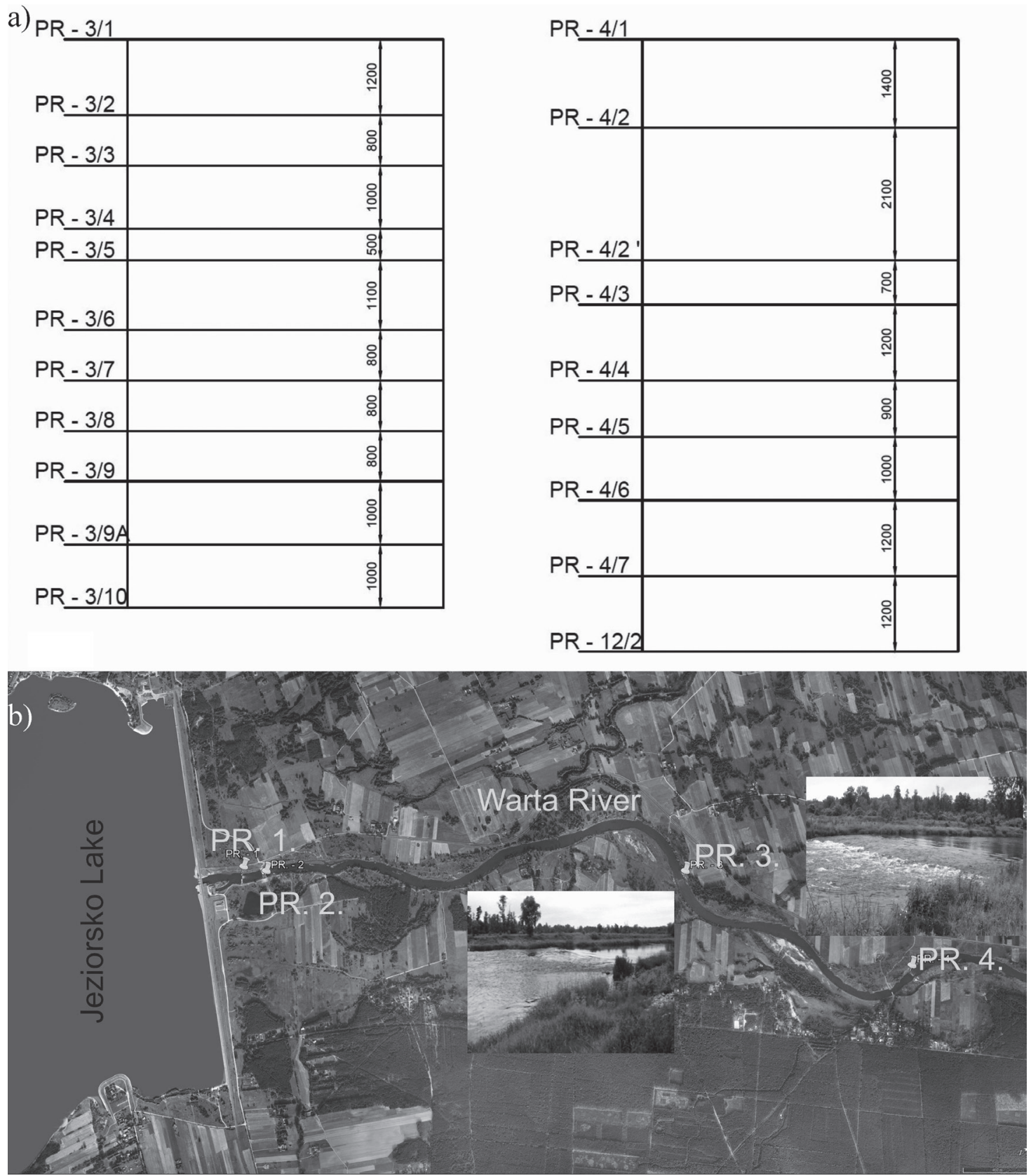

Fig. 1. View of weirs: A) sketch of the cross-section below sills PR -3 and $P R-4$, B) maps with locations of both weirs $-\mathrm{PR}-3$ $(480+902 \mathrm{~km})$ and $\mathrm{PR}-4(479+225 \mathrm{~km})$

\section{Materials and Methods}

\section{Selection of the Study Area and Field Study Methods}

The field research was carried out on the Warta River below Jeziorsko Reservoir, which is a typical lowland storage reservoir formed as a result of the damming of the river valley by an earthen dam and a concrete weir $67.5 \mathrm{~m}$ wide.

The paper presents selected results of in situ measurements after looking at graph data from 2007 to 2010. The measurements were made at a constant outflow rate of water from Jeziorsko Reservoir. A depth meter rod was used to determine the water depth and to plot the cross-sections. The ordinate of the water level was leveled at both sides of the cross sections using a TopCon Legacy-H GPS RTK receiver with a Satel radio and leveling instruments. The measurement results obtained from the depth probe along with the measurements of water level ordinates made it possible to obtain riverbed ordinates.

The study was conducted in 11 sections of weir No. 3 and eight sections of weir No. 4. Measurement cross-sections of water velocity were chosen upstream and downstream of both weirs (Fig. 1a). In 2007 hydrometric measurements were made downstream of weir No. 4, in sections PR-4/5 and PR-4/7 (Fig. 1a). 
The water velocity was measured in each of the sections, in 3 hydrometric verticals. In 2008 water velocity was measured downstream of weir No. 3 in section PR-3/8 and in three hydrometric levels. In 2009 water velocity measurements were made upstream and downstream of No. 3 and No. 4. On weir No. 3 measurements were made in cross sections PR-3/1 (upstream of No. 3), PR-3/9, PR-3/9A, and PR-3/10 (downstream of No. 3). On weir No. 4 measurements were made in cross sections PR-4/6, PR-4/7, and P-12/2 (downstream of weir No. 4). In 2010 velocity measurements were made on both No. 3 and No. 4 in cross-sections of PR-3/1, PR-3/10, PR-4/1, and PR-4/7. Stream Pro HEGA-2 and ADCP current meters were used for flow measurements. An acoustic doppler current profiler (ADCP) device generates an ultrasonic pulse sent from the surface to the bottom. When a pulse is sent to the bottom it is reflected from suspended particles in the flowing water and some of it returns to the ADCP and is transmitted. This instrument measures the Doppler shift frequency (its change) of the reflected pulses and calculates water velocity (Kasprzak, 2003) [31].

A similar possibility in bed load transportation is presented by HEC-RAS software, which allows additionally for modelling of pollution distribution in water bodies (communal wastewater and other water stressors) $[32,33]$.

\section{Calculating Velocity Distributions Using the SSIIM Mathematic Model}

The calculations of velocity distributions were made both upstream and downstream of the studied weirs (Fig. 1b). Measurements were made sequentially in 2007, 2008, 2009, and 2010. The cross-sections obtained in them were used to generate a numerical riverbed grid, which was implemented to model SSIIM. Based on the cross-sectional geometry, the measured water level, and known water flow we used HEC-RAS software to determine roughness coefficients for each weir.

In order to describe the turbulent flow, the averaged version of the Navier-Stokes equations was used in the form [34].

\section{Sediment Transport Calculations Using the SSIIM Model}

The process of local riverbed erosion is complex and many factors impact this phenomenon. To estimate the roughness coefficient in the SSIIM program two relationships were used: the Manning-Strickler formula and effective roughness of sand in sediment composition. The bedform height can be calculated based on the van Rijn [35] formula:

$$
k_{s}=3 d_{90}+1.1 \Delta\left(1-\exp \frac{-25 \Delta}{\lambda}\right)
$$

$\mathrm{k}$ is a roughness coefficient, $\mathrm{m}$

$d_{90}$ is the grain size sieve where $90 \%$ of the material is finer, $m$

$\Delta$ is bed form height, $\mathrm{m}$

$\lambda$ is bed form length, $m$

The parameters of bedform height such as $\Delta$ and $\lambda$ were calculated according to the Radecki-Pawlik [36] equation. The calculations were also done for $\mathrm{k}_{\mathrm{s}}=3 \mathrm{~d}_{90}$ $(\Delta=0)$.

The concentration of bed sediment affects the density of the water-sediment mixture and is the reason for changes in flow character, i.e., density current formation.

This phenomenon was incorporated into the NavierStokes equations:

$$
\rho_{s} g \frac{\partial c}{\partial z}
$$

...where $\mathrm{c}$ is volume concentration of sediment. This term will move the velocity profile in opposite directions, and increase or decrease the water velocity close to the Olsen bed [37].

Sediment transport is divided into two types: bed load and suspended load. In model SSIIM the bed load can be computed with specific bed load formulas, for example [37] (2):

$$
\frac{q_{b}}{d_{50}^{1.5} \sqrt{\frac{\left(\rho_{r}-\rho\right) g}{\rho}}}=0.053 \frac{\left[\frac{\tau-\tau_{c}}{\tau_{c}}\right]^{2.1}}{d_{50}^{0.3}\left[\left(\frac{\left.\rho_{r}-\rho\right) g}{v^{2} \rho}\right)\right]^{0.1}}
$$

...where the sediment particle diameter is denoted by $\mathrm{D}_{50}(\mathrm{~m}), \tau$ is bed shear stress $\left(\mathrm{N} \cdot \mathrm{m}^{-2}\right), \tau_{c}$ is the critical bed shear stress for movement of sediment particles $\left(\mathrm{N} \cdot \mathrm{m}^{-2}\right), \rho$ and $\rho_{r}$ are the density of water and sediments $\left(\mathrm{kg} \cdot \mathrm{m}^{-3}\right), v$ is the viscosity of the water, and $\mathrm{g}$ is the acceleration of gravity $\left(\mathrm{m} \cdot \mathrm{s}^{-2}\right)$

Total sediment transport was computed with the Engelund and Hansen formula [37] (3).

$$
q_{r}=0.05 \rho_{r} U^{2} \sqrt{\frac{d_{50}}{g \delta}}\left[\frac{\tau}{g\left(\rho_{r}-\rho\right) d_{50}}\right]^{\frac{3}{2}}
$$

...where sediment transport, $\mathrm{q}_{r}$, is given in $\left(\mathrm{kg} \cdot \mathrm{s}^{-1} \mathrm{pr}\right.$. $\mathrm{m}$ width). $U$ is the velocity $\left(\mathrm{m} \cdot \mathrm{s}^{-1}\right), \rho_{r}$ is the density of the sediments $\left(\mathrm{kg} \cdot \mathrm{m}^{-3}\right), \rho$ is the density of the water $\left(\mathrm{kg} \cdot \mathrm{m}^{-3}\right), \tau$ is the shear stress on the bed $\left(\mathrm{N} \cdot \mathrm{m}^{-2}\right), \mathrm{g}$ is the acceleration of gravity $\left(\mathrm{m} \cdot \mathrm{s}^{-2}\right)$ and $\mathrm{d}_{50}$ is the average sediment diameter (m). This version of the formula works in the SI system of units.

The following Ackers-White formula is given. The sediment concentration, $\mathrm{c}$, is then given in weight $\operatorname{ppm}\left(\mathrm{g} \cdot \mathrm{m}^{-3}\right)[36]$ : 


$$
c=\frac{d \delta}{h} C\left(\frac{F_{g r}}{A}-1\right)^{m}\left(\frac{U}{u_{*}}\right)^{n}
$$

...where $\mathrm{F}_{g r}$ is mobility number $(\mathrm{m}), \mathrm{h}$ is depth $\left(\mathrm{m} \cdot \mathrm{s}^{-1}\right), U$ is the velocity $\left(\mathrm{m} \cdot \mathrm{s}^{-1}\right), m, n, A, C$ are compute parameters, and $\mathrm{u}^{*}$ shear velocity $\left(\mathrm{m} \cdot \mathrm{s}^{-1}\right)$.

The values of proportionality coefficient were changed in formula (2) in the range from 0.053 to 0.0053 , that is, the value of tenfold less than reported in the literature [38]. The impact of changes of 2.1 exponents at relative shear stresses in formula (2) on the calculated maximum depth of erosion process was also tested.

In the SSIIM model, two stability criteria of an erodible riverbed were chosen. The first was associated with the reduction of critical shear stress, and the second was defined as a sand slide. Factor $\mathrm{K}$ is computed and multiplied by the critical shear stress for a horizontal surface to give the effective critical shear stress for a sediment particle with Brooks formula [39] (Fig. 2a.):

$K=-\frac{\sin \phi \sin \alpha}{\tan \theta}+\sqrt{\frac{\sin \phi \sin \alpha}{\tan \theta}-\cos ^{2} \phi\left[1-\left(\frac{\tan \phi}{\tan \theta}\right)^{2}\right]}$

...where $\alpha$ is the angle value between the direction of velocity vector near the bed and the channel direction, the slope angle is denoted by $\varphi$, and $\theta$ is slope parameter.

$\mathrm{K}$-factor calculated with Brooks formula is multiplied by the value of horizontal critical shear stress for sediment particles. The result of this product gives the value of the effective critical shear stress for sediment near the sloping bed.

The sand slide algorithm better fits the decrease of the computational grid on the border between the movable bed and the angle of bed slope defined by the computer user. This algorithm makes it possible to maintain a proper angle of movable bed slope, which is not bigger than the natural slope of the sediment material.

\section{Assumption of Mathematical Models}

\section{Model A}

Field model of the riverbed was prepared (the size of $40 \mathrm{~m}$ width and $200 \mathrm{~m}$ length) (Fig. 2b) to examine the most appropriate model with the application of SSIIM software (1989).

Once we determine the specific discharge $\mathrm{q}=7.04 \mathrm{~m}^{3} \cdot \mathrm{sm}$ based on Błażejewski's research [40], the depth of tailwater was $2.61 \mathrm{~m}$, and the average particle diameter was $\mathrm{d} 50=0.5 \mathrm{~mm}$ on the movable bed. The diameter of sediment particles was determined as $d_{50}=0.10 \mathrm{~m}$ in the section simulating a flexible weir apron, and the length of the weir was $40 \mathrm{~m}$.

This model was based on defined parameters: volumetric bedload flow rate in van Rijn formula, types of bedforms, turbulence models, and adding an extra term in the Navier-Stokes equations, which were the reasons for the near-bed velocity increase and application of developed algorithms describing the movement of bedload on a sloping bed. a)

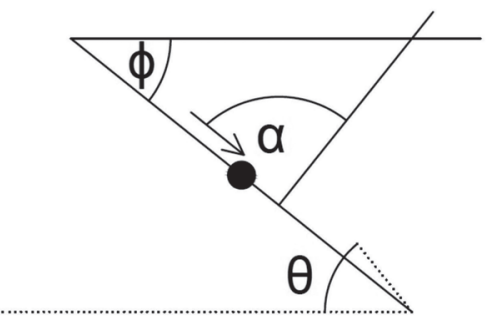

b)

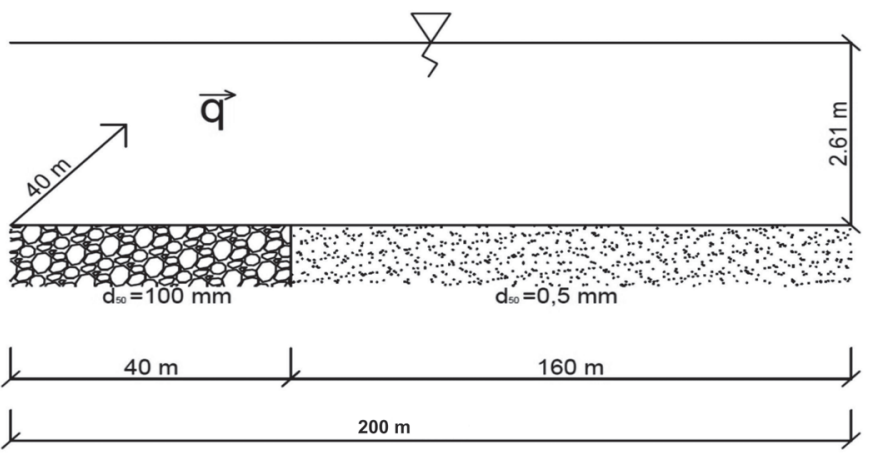

c)

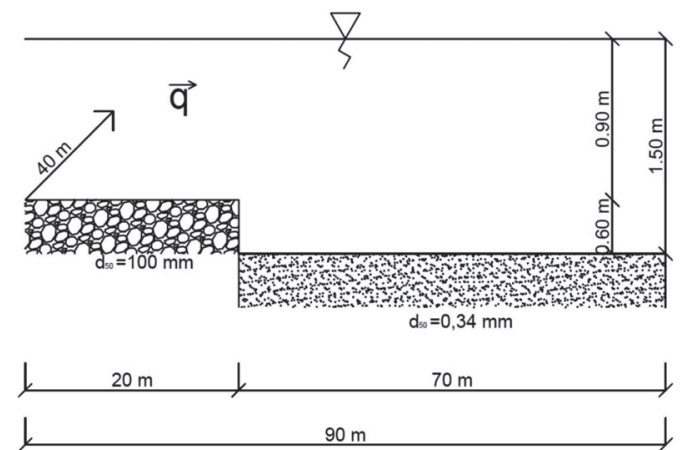


The following variables and constants in the SSIIM program were tested as an extra term in the NavierStokes equations, which take into account changes in the density of the water-sediment mixture, the stability criteria of the movable bed, turbulence model (k- $\varepsilon$ and $\mathrm{k}-\omega)$ exponent in the equation computing the volumetric bedload flow rate, and the effective roughness of the riverbed. The following formula was applied (2) rather than the standard methods of the Manning-Strickler equation. Also, the impact of threefold diameter value of sediment particles $d_{90}$ on the maximal depth of erosion processes was tested.

The influence of an extra term in the formula taking into account the changes in water density-sediment mixture is presented in Figs 5a) and 5b). Owing to this term in the algorithm for the reduction of critical shear stress and model $\mathrm{k}-\varepsilon$, the decrease of maximal depth of scour from $7.02 \mathrm{~m}$ to $5.53 \mathrm{~m}$, (i.e., about $25 \%$ )

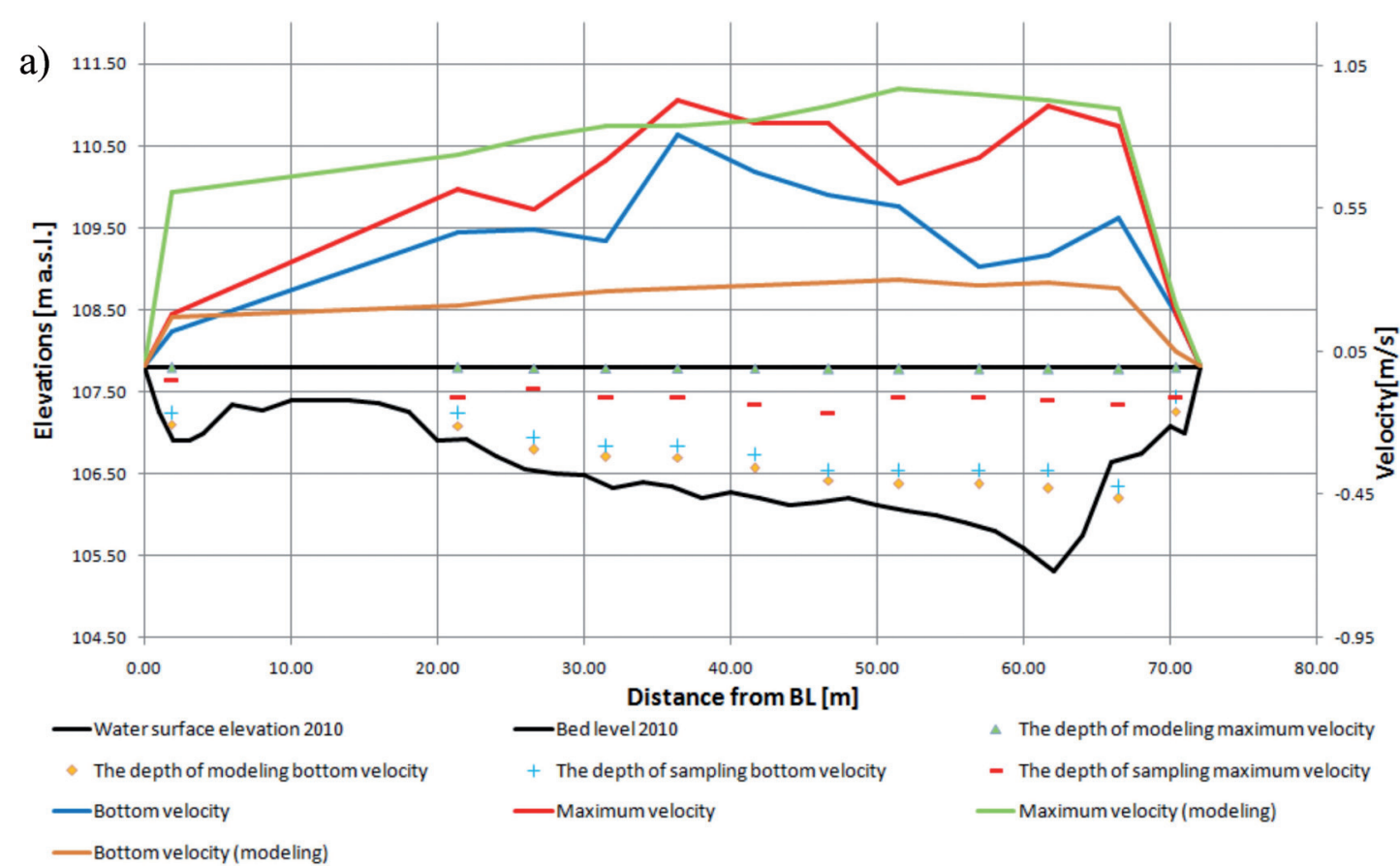

b)

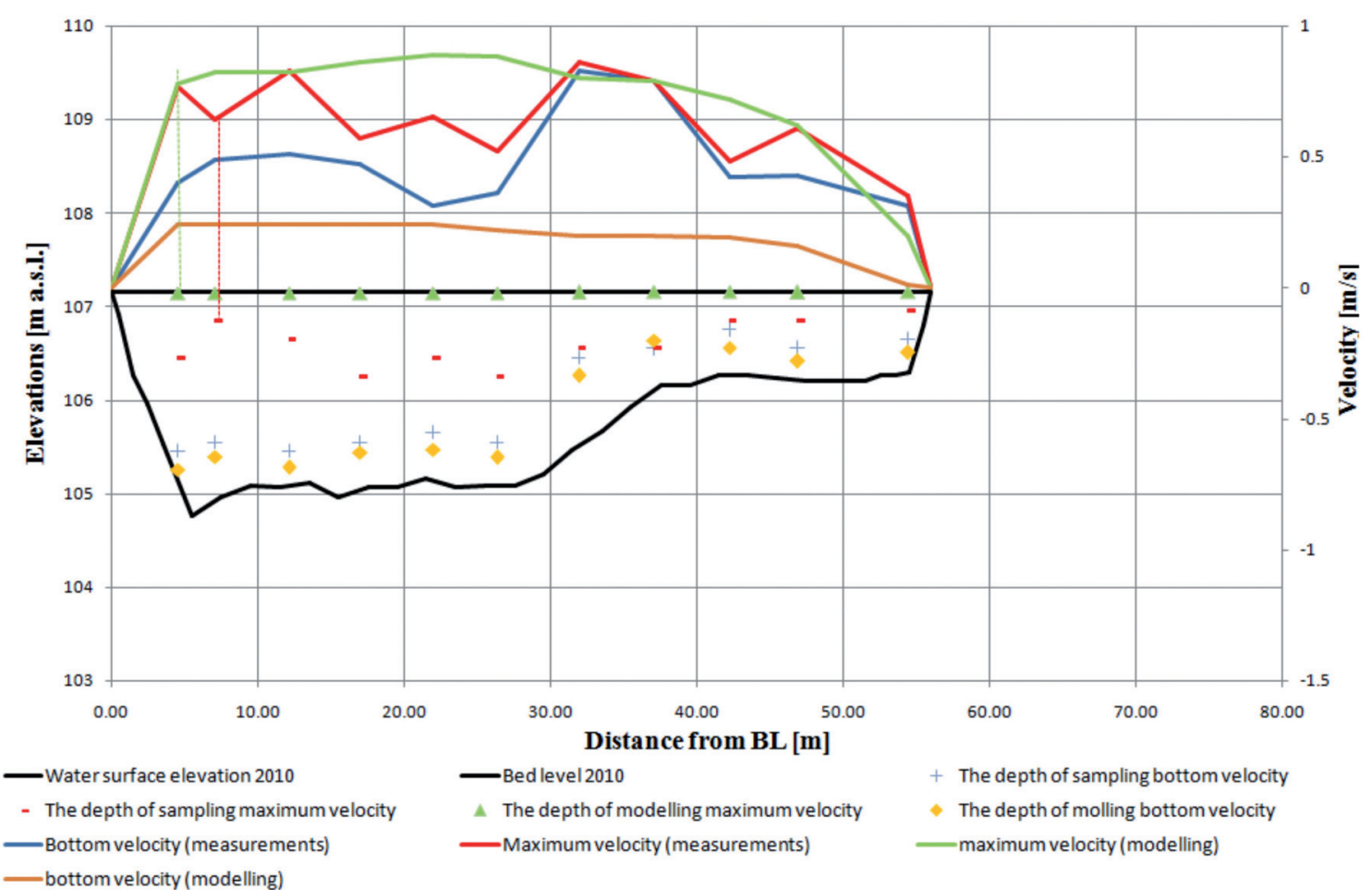

Fig. 3. Characteristic of velocity distributions in cross-section PR-3/10 (5.07.2010) a), and PR-4/7, (8 July 2010) b). 
was observed. To calculate the effective roughness the following formula was applied (1).

\section{Model B}

The sensitivity analysis of the tested model was performed. The authors tested the impact of the different size of sediment particles on the maximal depth of scour after 16 hours of simulation. Turbulence models ( $\mathrm{k}-\varepsilon$ and $\mathrm{k}=\omega$ ) were tested, and the calculations interchangeably used different values for reducing critical shear stress and the movement of bedload algorithms. In the mathematical formula, the relationship $\mathrm{k}_{\mathrm{s}}=3 \mathrm{~d}_{90}$ with the extra term in the Navier-Stokes equation was applied. Other mathematical parameters such as powers and constants in the formula describing the movable bed were used by default. The initial data were selected as shown in the scheme (Fig. 2c).

\section{Model C}

In the next stage of model simulations in SSIIM, parameters obtained as the result of experimental research conducted by Hämmerling [41] were applied. Determined model parameters were implemented in the calculations of erosion model of the riverbed in accordance with the Błażejewski model [40]. Fig. 2c) shows the results of calculations carried out when early development of local scour processes downstream on the Warta River behind the dam on Jeziorsko Reservoir is assumed.

a)

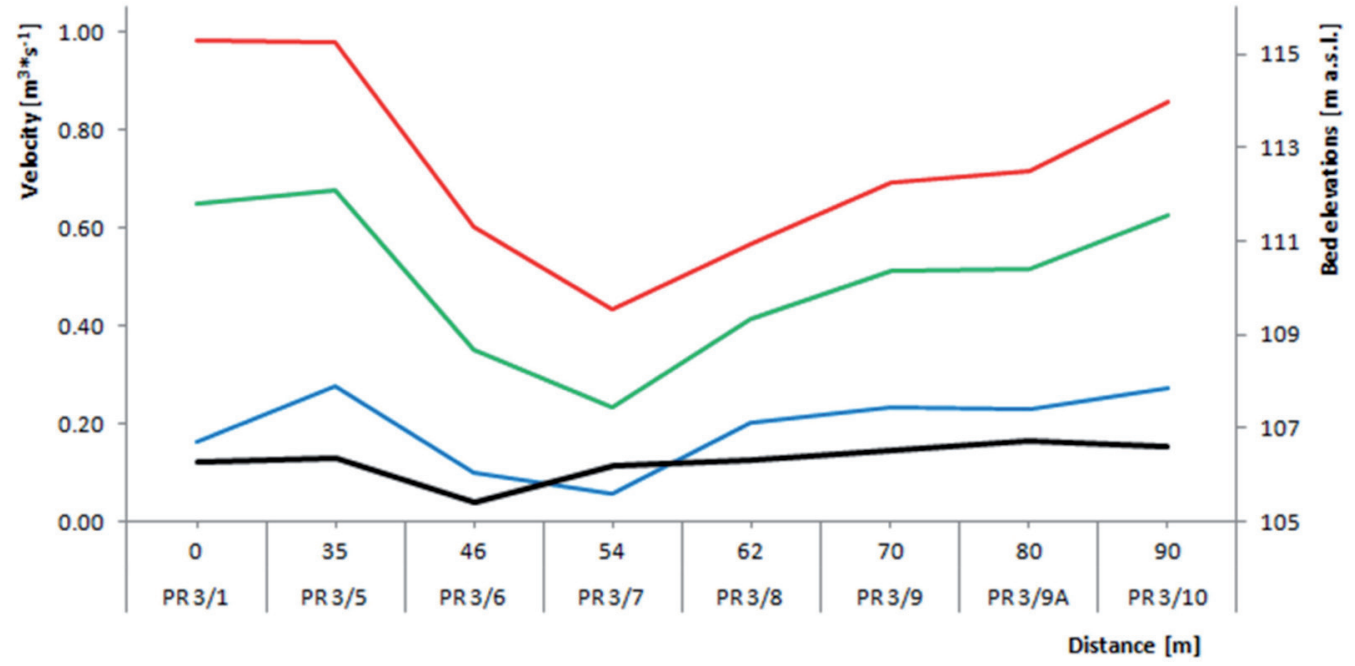

b)

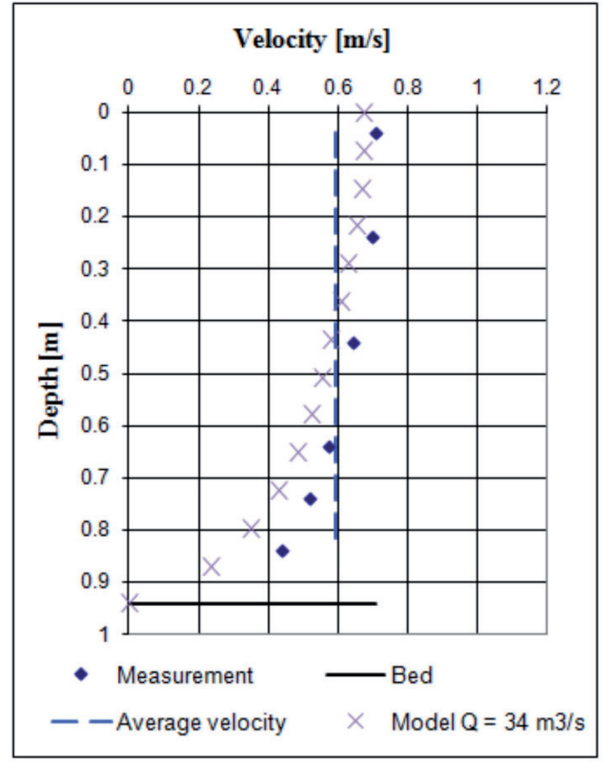

c)

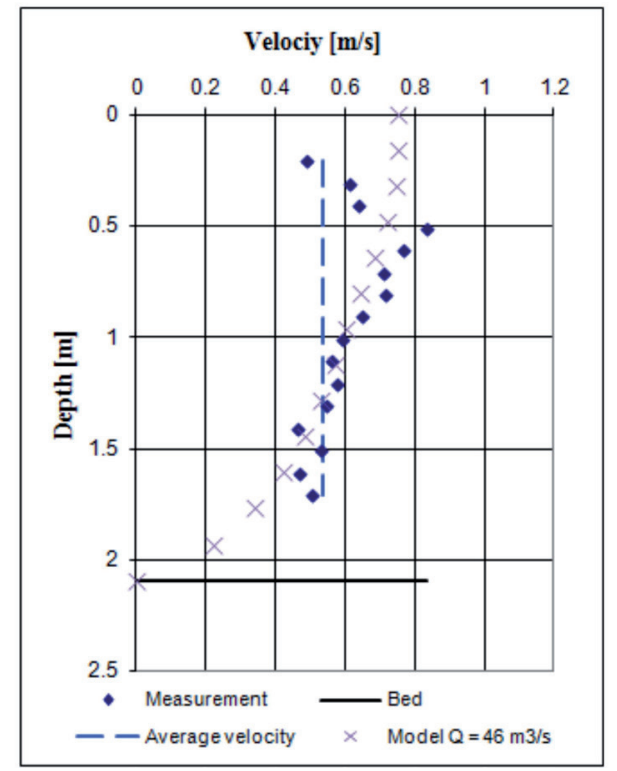

Fig. 4. Plot of the velocity of water in longitudinal profile No. 3, 2010 - a). and the velocity vertical profiles b) PR3/9A 53 m from BL, c) PR4/7 $12.13 \mathrm{~m}$ from BL. 


\section{Model D}

In the last stage of the model calculations we simulated the sediment movement below weir No. 3 on the Warta River in SSIIM software. In the models we implemented results of the measurements recorded in the period from July 2005 to Jun 2006. In the model we chose the algorithm presented in Fig. 2c). The thickness of the stone mattress was $0.60 \mathrm{~m}$, and the flow rate was taken as the highest intensity of discharge from the reservoir in the studied time $\mathrm{WQ}_{07.2005-06.2006}=60 \mathrm{~m}^{3} \cdot \mathrm{s}^{-1}$.

In the SSIIM program, the calculations were applied for fixed water flow and without the sediment inflow to the inflow cross-section. The authors computed the model of bedload movement (TrWL) with the application of the transient sediment computation algorithm (TSC). Similar to the other type of mode simulation, the same parameters as in the model formula were saved; the extra term in Navier-Stokes equation was applied, turbulence model was based on $(\mathrm{k}=\omega)$, and the sand slide algorithm was chosen for the angle $30^{\circ}$. In calculating sediment movement we applied Ackers and White's formula (4).

\section{Results}

\section{Velocity Distributions in Model SSIIM}

In 2010 the hydrometric measurements were made in cross-sections PR-3/1 and PR-3/10. The measurements were made at the outflow from reservoir $\mathrm{Q}=54 \mathrm{~m}^{3} / \mathrm{s}$ on 5 July 2010. In cross-section PR-3/10, the measurements were made in 12 hydrometrical verticals. With a width of water level equal to $72.0 \mathrm{~m}$, the average depth was $1.20 \mathrm{~m}$. The maximum velocities reached values from 0.81 to $0.12 \mathrm{~m} / \mathrm{s}$, while bottom velocities were from 0.76 to $0.05 \mathrm{~m} / \mathrm{s}$. Fig. 3a) shows the characteristic velocity in cross-section No. PR-3/10 in 2010.

In 2010 the hydrometric measurements were made in sections PR-4/1 and PR-4/7. The measurements were made at the outflow from reservoir $Q=54 \mathrm{~m}^{3} / \mathrm{s}$ on 8 July 2010 (Fig. 3B). In cross-section PR-4/7 11 hydrometric verticals were made. With a width of water level equal to $56.0 \mathrm{~m}$, the average depth $1.60 \mathrm{~m}$. The near-bed velocities were from 0.79 to $0.31 \mathrm{~m} / \mathrm{s}$. The maximum velocities took values from 0.83 to $0.35 \mathrm{~m} / \mathrm{s}$. The mean squared error for maximal velocities was 0.03 and for the bottom ones 0.1 .

In SSIIM software, the calculations of steady flow water conditions were made using the created numerical grid and known (data): flow rate, water level ordinate in the final cross-section, and obtained coefficient of roughness.

Fig. 4a) shows the characteristic velocity calculated using SSIIM model for the data from 2010.

The velocities obtained as a result of the mathematical model were similar to the ones recorded in the river. The highest values were taken on the weir while the lowest were in cross-sections of the largest erosion. The maximum velocity ranged from $0.98 \mathrm{~m} / \mathrm{s}$ to $0.43 \mathrm{~m} / \mathrm{s}$ (Fig. 4a). The average velocities for the verticals in the longitudinal profile of weir No. 3 ranged from $0.68 \mathrm{~m} / \mathrm{s}$ to $0.23 \mathrm{~m} / \mathrm{s}$, while the velocity near the bottom ranged from $0.28 \mathrm{~m} / \mathrm{s}$ to $0.06 \mathrm{~m} / \mathrm{s}$ (Fig. 4a). The velocity profile obtained using the mathematical model has a similar shape to the one measured in situ using the hydrometric current meter. The velocities

Table 1. Statistical measurements describing the velocity distributions in selected hydrometric levels [2].

\begin{tabular}{|c|c|c|c|c|c|}
\hline Hydrometric level & Distance from the left bank & Water depth in vertical & $S_{1}^{2}$ & $S_{2}^{2}$ & ts \\
\hline- & $\mathrm{m}$ & $\mathrm{m}$ & $\mathrm{m}^{2} / \mathrm{s}^{2}$ & $\mathrm{~m}^{2} / \mathrm{s}^{2}$ & - \\
\hline \multicolumn{6}{|c|}{ Cross sections PR-3/8, date 8.07. 2008, the outflow from the reservoir $\mathrm{Q}=28 \mathrm{~m}^{3} / \mathrm{s}$. } \\
\hline Level II & 33.0 & 1.7 & 0.01 & 0.02 & 1.73 \\
\hline \multicolumn{6}{|c|}{ Cross sections PR-3/9A, date 7.07. 2009, the outflow from the reservoir $\mathrm{Q}=34 \mathrm{~m}^{3} / \mathrm{s}$. } \\
\hline Level III & 53.0 & 1.0 & 0.01 & 0.00 & 1.65 \\
\hline \multicolumn{6}{|c|}{ Cross sections PR-3/10, date 5.07. 2010, the outflow from the reservoir $\mathrm{Q}=54.0 \mathrm{~m}^{3} / \mathrm{s}$} \\
\hline Level IX & 56.90 & 1.58 & 0.01 & 0.10 & -2.03 \\
\hline \multicolumn{6}{|c|}{ Cross sections PR- $4 / 5$, date 20.06 .2007 , the outflow from the reservoir $Q=28 \mathrm{~m}^{3} / \mathrm{s}$. } \\
\hline Level II & 26.5 & 1.7 & 0.01 & 0.06 & 0.07 \\
\hline \multicolumn{6}{|c|}{ Cross sections PR-4/7, date 10.10 .2009 , the outflow from the reservoir $Q=40 \mathrm{~m}^{3} / \mathrm{s}$. } \\
\hline Level I & 17 & 1.9 & 0.01 & 0.03 & -1.41 \\
\hline \multicolumn{6}{|c|}{ Cross sections PR-4/7, date 8.07 .2010 , the outflow from the reservoir $\mathrm{Q}=54 \mathrm{~m}^{3} / \mathrm{s}$} \\
\hline Level III & 12.13 & 2.09 & 0.01 & 0.02 & -1.49 \\
\hline
\end{tabular}


a) Legend
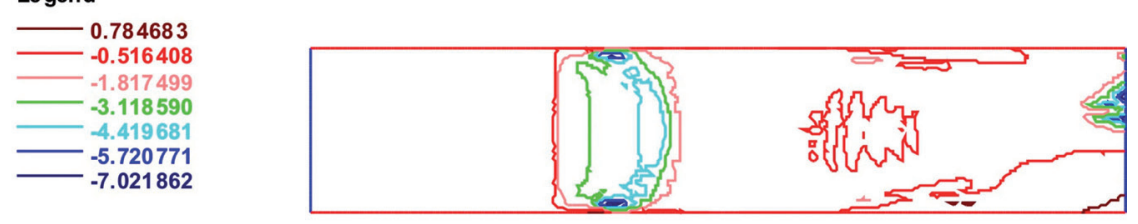

$50.0 \mathrm{~m}$

Bed leve $l$ changes, $\min =-7.0219 \mathrm{~m}, \max =0.7847 \mathrm{~m}$

b) Legend
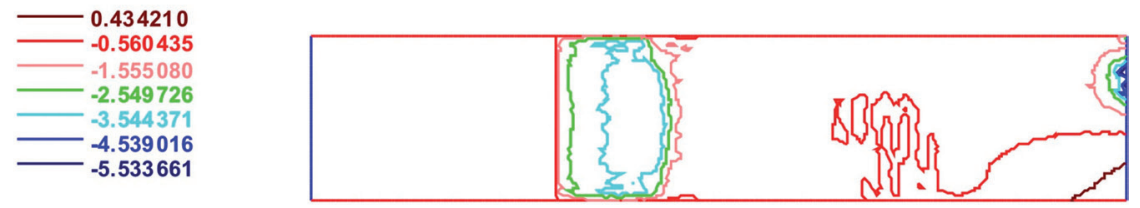

$50.0 \mathrm{~m}$

Bed leve $I$ changes, $\min =-5.5337 \mathrm{~m}, \max =0.4342 \mathrm{~m}$

c)

Legend

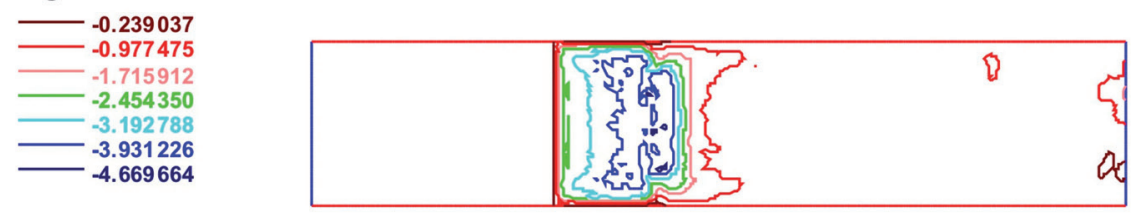

$50.0 \mathrm{~m}$

Bed level changes, $\min =-4.6697 \mathrm{~m}, \max =-0.2390 \mathrm{~m}$

d)
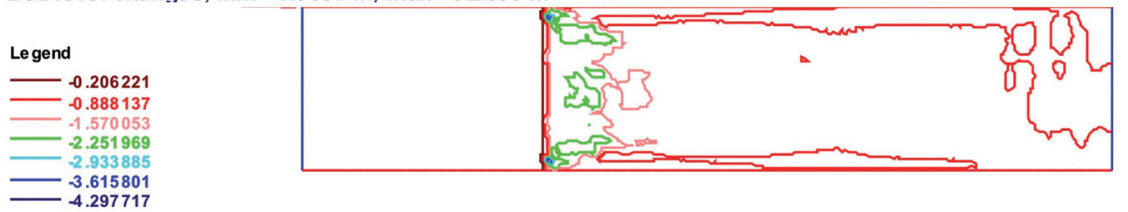

$50.0 \mathrm{~m}$

Be d level change s, $\mathrm{min}=-4.2977 \mathrm{~m}, \max =-0.2062 \mathrm{~m}$

e)

Legend
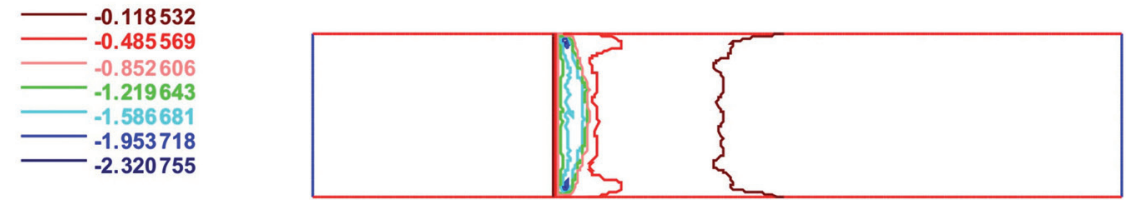

f)
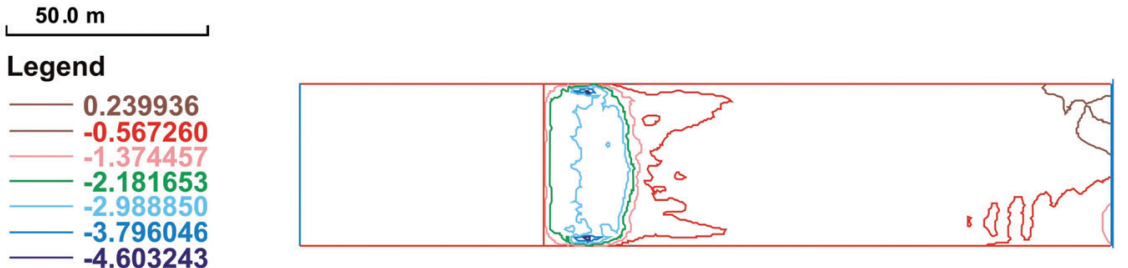

$50.0 \mathrm{~m}$

Bed level changes $\min =-4.6032, \max =0.2399 \mathrm{~m}$

Fig. 5. Changes in bed depth along the length of scour cross-section: a) without and b) with extra term in the Navier-Stokes formula, c) without the algorithm of critical shear reduction, d) turbulences model $\mathrm{k}-\omega$, e) constant in formula with the volumetric bedload flow rate $=0.0053$, and $\mathrm{f})$ with formula $(10)$ for $\Delta=0\left(\mathrm{k}_{\mathrm{s}}=3 \mathrm{~d}_{90}\right)$. 
simulated in the model take slightly lower values than the measured ones.

Figs 4b) and c) show a comparison of the velocity profile recorded in 2010 and calculated for the same conditions using the mathematical model.

The field measurements of water flow velocity were made using a Stream Pro ultrasonic anemometer, thanks to which we obtained the instantaneous velocity values in two directions in the horizontal plane. Velocity obtained in the model was accurately mapped only at the depth between $0.5 \mathrm{~m}$ and $1.5 \mathrm{~m}$. The results obtained in the mathematical model subsisted statistically as a test for the difference of mean values.

Table 1 summarizes the statistical measurements and compares the results of field measurements and of the mathematical model.

Absolute values of statistics for selected hydrometric levels take values 0.07-2.03. At predetermined level of significance $\alpha=5 \%$, we have no reason to reject the null hypothesis, i.e., that there is no significant difference between the mean values $(\alpha=5 \%$ refers only to the value of velocity measured and calculated in hydrometric verticals).
The linear correlation coefficient for the data on Fig.4b) was 0.93 and MSE $=0.008$, but for Fig. 4c) $\mathrm{R}=0.914$ and $\mathrm{MSE}=0.065$. Such values suggest high compatibility of velocity distributions obtained from the calculations and measurements.

\section{Results of Calculations of the Sediment Movement in Model SSIIM}

\section{Model A}

There the impact of the algorithm for reduction of critical shear stress on the maximal depth of the scour was tested (Figs 5a-b). In this simulation, the extra term in the Navier-Stokes formula was chosen and we used formula (1) in the effective roughness of the bed.

Figs 5(c-d) present the shape of the movable bed below the horizontal solid apron, which is dependent on the turbulence model. In calculations we used the extra term in the Navier-Stokes formula, and without the algorithm of critical shear reduction, and it was used in calculating effective roughness of the bed the formula (10).

a)

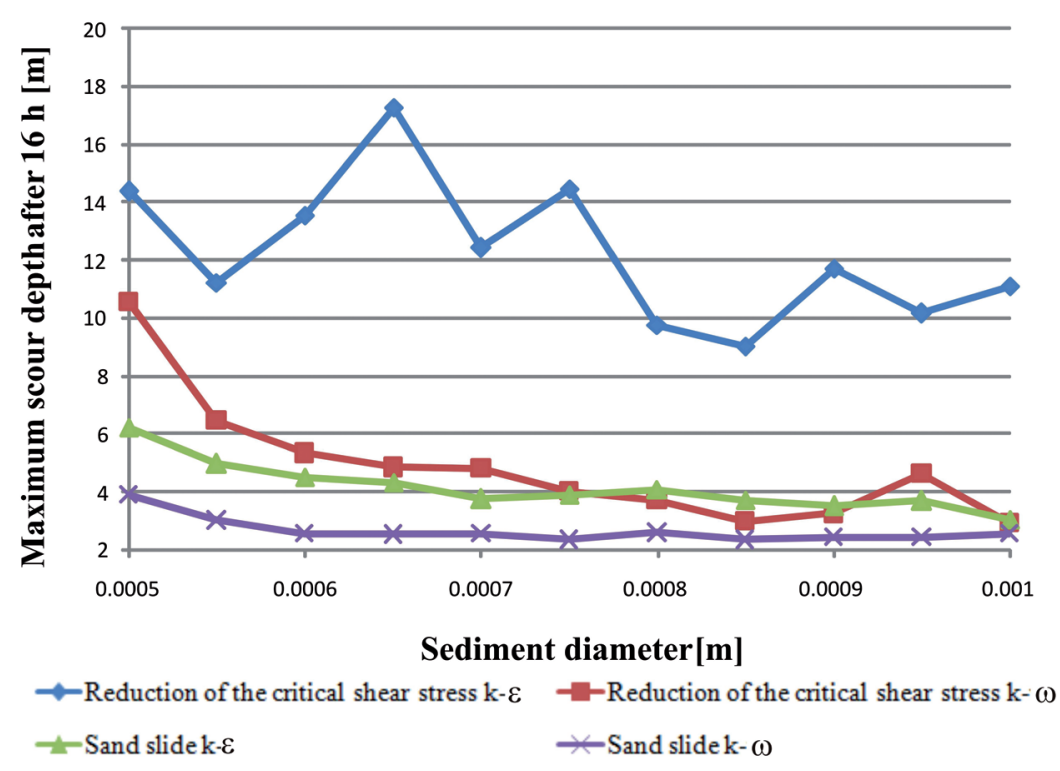

b)

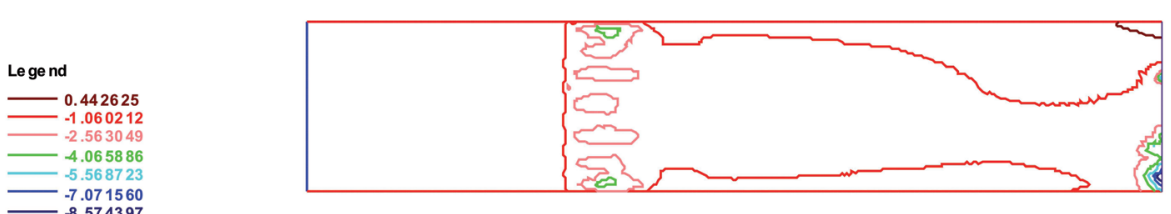

$50.0 \mathrm{~m}$
Bed level changes, $\min =-8.5744 \mathrm{~m}, \max =0.4426 \mathrm{~m}$

Fig. 6. a) Scour depth erosion changes after $16 \mathrm{~h}$ and b) contour map of the riverbed below Jeziorsko Reservoir. 
In research (Figs 5d-e), the impact of various constants in the formula with the volumetric bed load flow rate on bed depth was tested. Simulation enabled critical shear reduction function and the extra term in the Navier-Stokes formula, the turbulence model k- $\varepsilon$.

The influence of the coefficient in the formula of the bed load transport was examined according to Van Rijn. The results for the default factor equalling 0.053 are presented in Fig. 5b) and at 0.0053 in Fig. 5e) (according to new numbering).

The application of the two dependents describing bed effective roughness in SSIIM was also tested. It selected dependents: (10 - Fig. 5b) and $\mathrm{k}_{\mathrm{s}}=3 \mathrm{~d}_{90}$ (Fig. 5f).

\section{Model B}

Fig. 6a) presents results from the model of the maximal depth of local scour after 16 hours of simulation for variously sized sediment particles in bed load composition.

\section{Model C}

Fig. 6b) presents the results of mathematical modelling of an erodible riverbed downstream of Jeziorsko Reservoir.
Changes in the riverbed structure (Fig. 6b) were compared to the results obtained in mathematical modelling for the same input parameters during model verification. There is a significant difference observed, in particular in the section of the river mouth (where the measurements were taken).

\section{Model D}

Fig. 7a) clearly presents an example of a contour map of the riverbed after 44 hours of erosion processes, and Fig. 7b) shows changes in maximal and average depths of the biggest local scour below the weir, e.g., 3 in time are shown.

\section{Discussion}

Statistical analysis allowed us to accept the null hypothesis at an assumed level of significance $\alpha=0.05$. The most convergent results were obtained for the hydrometric vertical PR-4/5 $26.50 \mathrm{~m}$ from BL recorded in 2007. The least convergent results were obtained for the hydrometric vertical PR-3/10 $56.90 \mathrm{~m}$ from BL. Other authors reported similar results of their studies [42, 43].
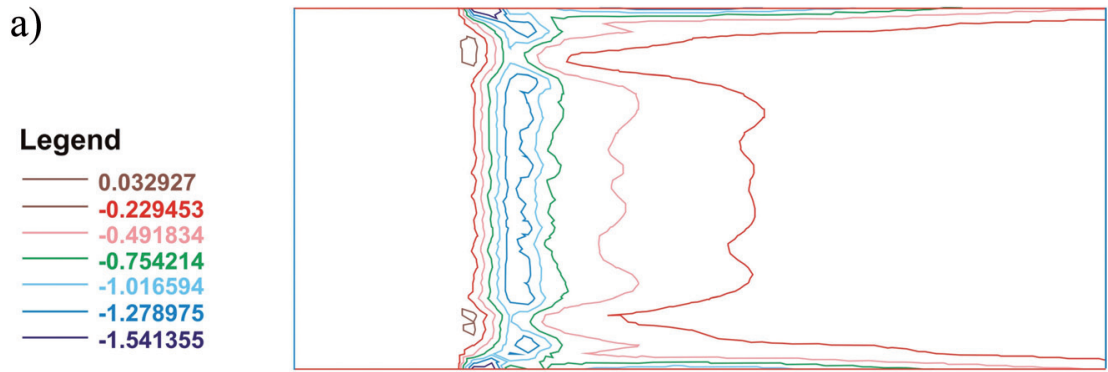

$20.0 \mathrm{~m}$

Bed level changes $\min =-1.5414, \max =0.0329 \mathrm{~m}$

b)

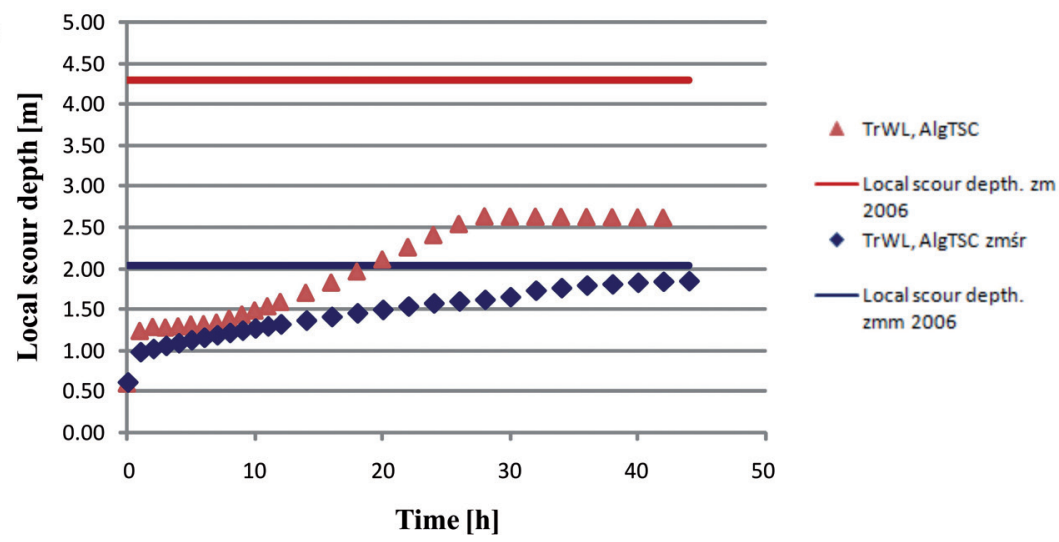

Fig. 7. a) Erosion changes in maximal bed depths below weir No. 3 and b) contour map of the riverbed below weir No. 3 . after 44 hours of erosion processes. 
Based on Błażejewski's model assumptions, the authors include in calculations of their results of field studies the early stage of reservoir exploitation. Błażejewski presented a deterministic-probabilistic model of local scour in the non-cohesive soil below the horizontal solid apron. Błażejewski verified his model in field studies of the local scour processes in 1983-1987 behind Jeziorsko Reservoir on the Warta River. The maximum depth of the scour below solid aprons was then $4.6 \mathrm{~m}$.

Identifying the model was based on an analysis of the impact of variables and parameters on the obtained results. The algorithm for the reduction of critical shear stress yielded a decrease of the maximum depth of the bed from $5.53 \mathrm{~m}$ to the $4.67 \mathrm{~m}$, or about $18 \%$, in comparison to the situation without this function in the model simulation (Figs 5a-b).

During the mathematical modelling, different turbulence models were examined in terms of the riverbed erosion patterns.

A similar algorithm was applied by many authors in sedimentology research papers [44, 45]. For the defined assumptions model $\mathrm{k}-\varepsilon$ was characterized by maximal depth on scour equal to $4.67 \mathrm{~m}$, and in model $\mathrm{k}-\omega-4.30 \mathrm{~m}$, i.e. about $8 \%$ (Figs $5 \mathrm{c}-\mathrm{d}$ ). The influence of the different types of turbulence on the sediment transport both in river and sea conditions was investigated by many scientists in the research area of hydrology and fluid mechanics [43, 46-48].

Figs 5e-f) show the impact of the constant reduction in the van Rijn equation on volumetric bedload flow rate (from 0.053 to 0.0053 ) formula (2). A tenfold reduction of constant value caused a decrease of bed maximal depth after 16 hours of simulation from $5.53 \mathrm{~m}$ to 2.32 $\mathrm{m}$, i.e., by about $42 \%$. In scientific literature different formulas describing the model of bedload sediment transport were reported [49-51]. In presented research, such a high reduction was required because of the investigated bed load sediment material composition. Przedwojski in his research described a physical model of bedload sediment transport on the Warta River and revealed that the van Rijn formula must be modified [38].

The last parameter in the model identification was the different formulas to determine the roughness coefficient of the riverbed. In this study, an algorithm for critical shear stress reduction, the extra term in NavierStokes equation, and the turbulence model $\mathrm{k}-\varepsilon$ were used. The model with the $\mathrm{ks}=3 \mathrm{~d}_{90}$ gave a reduction of maximal depth of bed from $5.53 \mathrm{~m}$ to $4.60 \mathrm{~m}$, i.e., by about 20\%. (Fig. 5f) [52]. Other authors applied the van Rijn formula in their investigations in different models of bed load transport both for rivers and sea areas [52-56].

In all the above-described models of the identification process, the implemented time of simulation was 16 hours. The model of implementation of local scour in SSIIM revealed that the best results were obtained when the extra term in the Navier-Stokes equation, and the effective bed roughness $\mathrm{k}_{\mathrm{s}}=3 \mathrm{~d}_{90}$, were incorporated into SSIIM. Better results were obtained when the constant $=0.053$ was used in the van Rijn formula.

The sensitivity analysis of the computed model B (Fig. 6a) revealed that yielded unstable result using the $\mathrm{k}-\varepsilon$ model with the algorithm for critical shear stress reduction. The values of maximal bed depth of the local scour were much higher than those obtained in the other three combinations of models after 16 hours of simulation. The application of the function for critical shear stress reduction generated greater depths than the sand slide algorithm. The k-Emodel revealed higher and less realistic maximal depths of the local scour than the model $\mathrm{k}-\omega$ model [56], as the diameter of the particles of the movable sediment material increases the depth of scour reveal. By conducting the above analysis, the most important factors influencing the changes in the bed load transport models [57-60] were identified. The sand slide algorithm gave results that were less sensitive to the changes in the diameter of particles of movable bed sediment than critical shear stress reduction function $[5,41]$.

The model C (Fig. 6b) analysis was conducted for a steady flow of water with bedload movement (TrWL), without sediment particle inflow to the inlet crosssection. During calculations in the SSIIM program, none of the following relations changed: the extra term in Navier-Stokes formula was included, $\mathrm{k}-\varepsilon$ model was applied, and the sand slide algorithm wasn't included for an angle of $30^{\circ}$. In the calculations of bedload transport, Ackers and White's formula (3) was used, and the transient sediment computation algorithm (TSC) was applied as well.

There were differences observed between the obtained models as a result of the effects of scale, and directly through the influence of the included parameters in mathematical formulas [40].

The results obtained with model D (Figs 7a-b) clearly show the stabilization of scour in time after 28 hours of erosion processes. The maximal depth of the analyzed scour was $4.3 \mathrm{~m}$ in 2006 , and the average cross-section only $2.04 \mathrm{~m}$. This demonstrates the uneven flow distribution of the specific discharges on bed width, and/or locally differentiated susceptibility to the erosion of the bed material [61]. The results show that the difference between average depths in scour (the calculated one and the measured one) in sections with the highest depths is relatively small at only $9 \%$ (Fig. 7b). Similar reports have been published by other authors [62-64]. It was found that model SSIIM is highly sensitive to the boundary conditions, which are often difficult for mapping, especially for flexible weir (with flexible aprons made of a material susceptible to deformation and erosion) located in the curved parts of the river. Analyses of the impact of the parameters of the mathematical model on the results were also conducted in papers by Lehnhäuser and Schäfer, and $\mathrm{Hu}$ and Wang $[65,66]$. 
Teraguchi et al., Noh et al., and Zhang et al. [67-69] applied their models of bed load transport for specific case study parameters. SSIIM models proposed by authors can be easily adapted to their calculations.

\section{Conclusions}

SSIM is a valuable tool for modelling destructive hydraulic phenomena, including riverbed erosion. A properly calculated model allows for predicting changes in local riverbed scour geometry. Based on obtained results, it will be easy to plan the necessary investments to protect against damage to river weir construction.

Our paper presents the results of field studies on velocity distributions conducted in 2007-2010 upstream and downstream of weirs No. $3(\mathrm{~km} \mathrm{480+902)}$ and No. $4(\mathrm{~km} \mathrm{479+225).} \mathrm{Based} \mathrm{on} \mathrm{the} \mathrm{field} \mathrm{measurements,}$ which were recorded and implemented in the SSIIM environment, a mathematical model was built.

The authors also presented a mathematical model of bed load transport directly below the dam of the Warta River. Mathematical models of bed load transport for two research areas downstream of Jeziorsko Reservoir on the Warta were computed.

There was no significant difference between the mean calculated and measured velocities at a given significance level $\alpha=5 \%$. When analyzing the statistical data describing all measured and calculated velocities, it was concluded that model results were more compatible with measurements obtained from the regular current meter than those obtained with the ultrasonic Stream Pro anemometer.

The results of modelling studies of programmers SSIIM demonstrate the process of identification and verification of the mathematical model of the bed load transportation in the area of local scours (Models A and B). A comparison of the theoretical model with the physical one from the field research revealed that the best results were obtained with the application in the model of the extra term in Navier-Stokes formula, effective bed roughness $\mathrm{k}_{\mathrm{s}}=3 \mathrm{~d}_{90}$, and the constant in the formula with the volumetric bedload flow rate $=0.053$ as van Rijn proposed.

The analyses also used SSIIM model parameters verified in field research of local scour processes. The parameters obtained from the verification of the model in accordance with Błażejewski's assumption (Model C) were implemented, and it was found that the maximum depth of scour below the solid apron was about $4 \mathrm{~m}$, which is approximately consistent with Błażejewski’s results.

The results of Model D indicate minor differences between the calculated and the measured average depths in the cross-section of maximal scour.

The difference between the measured and the calculated maximum depths indicates an uneven flow distribution of the specific discharges on the bed width of the channel and/or locally differentiated susceptibility to the erosion of the bed material.

The chart (Fig. 7b) shows that the difference between the average depths of local scour (computed and measured ones) in cross-sections is only $9 \%$.

The SSIIM mathematical model can be used to simulate the velocity distributions downstream of the weir. It was found that the SSIIM model is highly sensitive to boundary conditions, which are often difficult for mapping, especially for flexible weir (with flexible aprons made of a material susceptible to deformation and erosion) located in the meandering parts of the river.

\section{Acknowledgement}

Paper has been prepared within the scope of the AGH UST statutory research no. 11.11.150.949. and UP - Poznan NCN general grants no. 2084/B/P01/2009/37.

\section{Conflict of Interest}

The authors declare no conflict of interest.

\section{References}

1. BISANTINO T., GENTILE F., MiLELLA P., LIUZZI G.T. Effect of time scale on the performance of different sediment transport formulas in a semiarid region. Journal of Hydraulic Engineering.. 136, 1, 56, 2009.

2. WIERZBICKI M., HÄMMERLING M., PRZEDWOJSKI $B$. The influence of weirs on the formation of the water level and the bottom level downstream of Jeziorsko reservoir. Water Management. 6, 239, 2011.

3. LAKS I., KAŁUŻA T., SOJKA M., WALCZAK Z., WRÓŻYŃSKI R. Problems with Modelling Water Distribution in Open Channels with Hydraulic Engineering Structures, RocznikOchronaŚrodowiska 15, 245, 2013.

4. NIEĆ J., ZAWADZKI P., WALCZAK Z., SPYCHAŁA M. Calculating earth dam seepage using HYDRUS software applications.Acta Sci. Pol. FormatioCircumiectus, [In Press].

5. DYSARZ T., WICHER-DYSARZ J. Application of hydrodynamic simulation and frequency analysis for assessment of sediment deposition and vegetation impacts on floodplain inundation. Polish Journal of Environmental Studies. 20 (6), 1441, 2011,

6. URBAŃSKI J., SIWICKI P. The application of a computer software FLUENT CFD, for the calculation of the characteristics of turbulence in downstream of weir. Infrastructure and ekology of rural areas. 2 (4), 201, 2007.

7. CELLINO M., GRAFF W.H. Experiments on suspension flow in open channels with bed forms. Journal of Hydraulic Research. 38 (4), 289, 2000.

8. TERMINI D., SAMMARTANO V. Flow kinematic characteristics in the scour hole downstream of a grade control structure In Congress on Environmental Modelling and Software Modelling for Environment's Sake. 2010. 
9. URBAŃSKI J. Eksperymentalne badania wpływu szykan na długość odskoku hydraulicznego. Acta Sci. Pol., FormatioCircumiectus, 14 (1), 189, 2015.

10. TERMINI D. Bed scouring downstream of hydraulic structures under steady flow conditions: Experimental analysis of space and time scales and implications for mathematical modelling. Catena. 84 (3), 125, 2011.

11. RADECKI-PAWLIK A., RADECKI-PAWLIK B. Wyznaczenie bezwymiarowej wartości parametru początku ruchu rumowiska wleczonego za pomocą wybranych formuł empirycznych. Acta Sci. Pol., FormatioCircumiectus, 14 (4), 95, 2015.

12. LIRIANO SARAH L., DAY RODNEY A., RODNEY WHITE W. Scour at culvert outlets as influenced by the turbulent flowstructure. Journal of Hydraulic Research. 40 (3), 367, 2002.

13. OLIVETO G.,COMUNIELlO V., BULBULE T. Timedependent local scour downstream of positive-step stilling basins. Journal of Hydraulic Research. 49 (1), 105, 2011.

14. D'AGOSTINO V., FERRO V. Scour on alluvial bed downstream of grade-control structures. Journal of Hydraulic Engineering. 130 (1), 24, 2004.

15. ESPA P., SYBILLA S. Experimental study of the scour regimes downstream of apron for intermediate tailwater depths. River Flow. Taylor \& Fransis Group, London, ISSN: 1735-3572.1715-1717. 2006.

16. CHEN Z., SHAO X., ZHANG J. Experimental study on the upstream water level rise and downstream scour length of a submerged dam. Journal of Hydraulic Research. 43 (6), 703, 2005.

17. BENNETT S.J., ALONSO C.V. Turbulent flow and bed pressure within headcut scour holes due to plane reattached jets. Journal of Hydraulic Research. 44 (4), 510, 2006.

18. SHEN L., LU C., WU W., XUE S. High-Order Numerical Method to Study Three-Dimensional Hydrodynamics in a Natural River. Advances in Applied Mathematics and Mechanics. 605, 180, 2015.

19. BARRIOS-PIÑA H., RAMÍREZ-LEÓN H., RODRÍGUEZ-CUEVAS C., COUDER-CASTAÑEDA C. Multilayer Numerical Modelling of Flows through Vegetation Using a Mixing-Length Turbulence Model, Water. 6, 2084, 2014.

20. SALEM-SAID A.H., FAYED H., RAGAB S. Numerical Simulations of Two-Phase Flow in a Dorr-Oliver Flotation Cell Model. Minerals. 3 (3), 284, 2013.

21. KAIGLOVÁ J., LANGHAMMER J., JIŘINEC P., JANSKÝ B., CHALUPOVÁ D. Numerical simulations of heavily polluted fine-grained sediment remobilization using 1D, 1D+, and 2D channel schematization. Environmental Monitoring and Assessment. 187 (3), 1, 2015.

22. ELHAKEEM M., SATTAR A. An entrainment model for non-uniform sediment. Earth Surface Processes and Landforms. 40 (9), 1216, 2015.

23. DYSARZ T., WICHER-DYSARZ J., SOJKA M. Two approaches to forecasting of sedimentation in the Stare Miasto reservoir, Poland. Reservoir Sedimentation.ISBN 978-1-138-02675-9.119-127. 2014.

24. PLESIŃSKI K., MAREK A., SKALICZ F., RADECKIPAWLIK A. Wykorzystanie modelu komputerowego basegrain do analizy składu granulometrycznego rumowiskawleczonego potoku ponikiewka metodą fotograficzną. Acta. Sci. Pol., Formatio Circumiectus, 16 (1), 107, 2017

25. TREGNAGHI M., MARION A., BOTTACIN-BUSOLIN A., TAIT S.J. Modelling time varying scouring at bed sills.
Earth Surface Processes and Landforms. 36 (13), 1761, 2011.

26. ZAHIRI A., AZAMATHULLA H.M., GHORBANI K. Prediction of local scour depth downstream of bed sills using soft computing models. In Computational Intelligence Techniques in Earth and Environmental Sciences. 197-208. Springer Netherlands.2014.

27. JAFARI E., HASSUNIZADEH H., ZAREDEHDASHT E., KIUANI M. Estimating Scour Depth Around Bridge Piles Using Ssiim Software and Comparingits Results with Physical Model Results. Australian Journal of Basic and Applied Sciences. 5 (7), 167, 2011.

28. ZINKE P., OLSEN N.R.B., BOGEN J., RÜTHER N. 3D modelling of the flow distribution in the delta of Lake Øyeren, Norway. Hydrology Research. 41 (2) 92, 2010.

29. WILSON C.A.M.E., BAXALL J.B., GUYMER I., OLSEN N.R.B. Validation of a Three-Dimensional Numerical Code in the Simulation of Pseudo-Natural Meandering Flows. Journal of Hydraulic Engineering. 129 (10), 758, 2003.

30. HÄMMERLING M., BŁAŻEJEWSKI R., WALCZAK N. Modelling of local scour in non-cohesive soils below sills using SSIIM computer code. RocznikOchronaŚrodowiska. 15 (1), 538, 2013.

31. KASPRZAK K. Integrative methods of flow measurement. IMGW, Warszawa. 2003.

32. BUGAJSKI P., CHMIELOWSKI K., KACZOR G. Optimizing the Percentage of Sewage from SepticTanks for Stable Operation of a Wastewater Treatment Plant. Polish Journal of EnvironmentalStudies, 25 (4), 2016.

33. CHMIELOWSKI K., ŚLIZOWSKI R. Effect of grain-size distribution of sand on the filtrate quality invertical-flow filters. PrzemysłChemiczny. 87 (5), 432, 2008.

34. OLSEN N.R.B. A three dimensional numerical model for simulation of sediments movements in water intakes with multiblock options. The Norwegian University of Science and Technology. http://folk.ntnu.no/nilsol/ssiim/manual3. pdf. 2009

35. VAN RIJN L.C. Mathematical modelling of morphological processes in the case of suspended sediment transport. Ph. D. thesis. Delft University of Technology. 1987.

36. RADECKI-PAWLIK A., KSIĄŻEK L. The morphology and morphodynamics of sand-gravel subaquatic dunes: the Raba River estuary, Poland. GEOREVIEW: Scientific Annals of Stefan cel Mare University of Suceava. Geography Series. 21 (1), 8, 2012.

37. OLSEN N.R.B. Numerical Modelling and Hydraulics. The NorvegianUniverity of Science and Technology. ISBN 827598-074-7.2007.

38. PRZEDWOJSKI B., BŁAŻEJEWSKI R., PILARCZYK K.W. River training techniques: fundamentals, design and applications. AA Balkema. Rotterdam. 1995.

39. BROOKS H.N. Discussed of "Boundary Shear Stresses in Curved Trapezoidal Channels", by Ippen A. T. and Drinker P. A., ASCE Journal of Hydraulic Engineering. 89, 3, 1963.

40. BŁAŻEJEWSKI R. Forecasting the local scour of non-cohesive soils below the sluice gate. Yearbooks of Agricultural University of Poznan. UR - Publisher. 190, 1989.

41. HÄMMERLING M. Forecasting the erosion changes in the bottom of the riverbed downstream of the weirs. Doctoral thesis. manuscript: University of Life Science in Poznań. 2012.

42. HILLEBRAND G., KLASSEN I., OLSEN N.R.B. 3D CFD modelling of velocities and sediment transport in 
the Iffezheim hydropower reservoir, Hydrology Research, 47 (4), 2015.

43. KURNATOWSKI J. Comparison of analytical and numerical solutions for steady, gradually varied openchannel flow. Pol. J. Environ. Stud 20 (4), 925, 2011.

44. HARB G., HAUN S., SCHNEIDER J., OLSEN N.R.B. Numerical analysis of synthetic granulate deposition in a physical model study. International Journal of Sediment Research 29 (1), 110, 2014.

45. KHOSRONEJAD A.,KOZAREK J.L., SOTIROPOULOS F. Simulation-Based Approach for Stream Restoration Structure Design: Model Development and Validation. Journal of Hydraulic Engineering. 140 (9), 04014042, 2014.

46. XIA J., LIN B., FALCONER R. A., WANG G. Modelling dam-break flows over mobile beds using a 2D coupled approach. Advances in Water Resources. 33 (2), 171, 2010.

47. PULEO J.A., LANCKRIET T., CONLEY D., FOSTER D. Sediment transport partitioning in the swash zone of a large-scale laboratory beach. Coastal Engineering, 113, 73, 2016.

48. CHEN X., LI Y.,NIU X., LI M., CHEN D., YU X. A general two-phase turbulent flow model applied to the study of sediment transport in open channels. International Journal of Multiphase Flow. 37 (9), 1099, 2011.

49. DYSARZ T., WICHER-DYSARZ J. Application of hydrodynamic simulation and frequency analysis for assessment of sediment deposition and vegetation impacts on floodplain inundation. Pol. J. Environ. Stud, 20 (6), 1441, 2011.

50. FANG H.W., LAI R.X., LIN B.L., XU X.Y., ZHANG F.X., ZHANG Y.F. Variational-based data assimilation to simulate sediment concentration in the Lower Yellow River, China. Journal of Hydrologic Engineering, 21 (5), $04016010,2016$.

51. MOSSELMAN E., LE T.B. Five common mistakes in fluvial morphodynamicmodelling. Advances in Water Resources. 93, 15, 2016.

52. NICHOLAS A.P., ASHWORTH P.J., SAMBROOK SMITH G.H., SANDBACH S.D. Numerical simulation of bar and island morphodynamics in anabranchingmegarivers. Journal of Geophysical Research: Earth Surface, 118 (4), 2019, 2013.

53. KNIGHTON D. Fluvial forms and processes: a new perspective. Routledge. ISBN: 13:978-0-340-66313-4.2014.

54. JULIEN P.Y. Erosion andsedimentation. Cambridge University Press. ISBN 978-0-521-83038-6. 2010.

55. SUN R., XIAO H. SediFoam: A general-purpose, open-source CFD-DEM solver for particle-laden flow with emphasis on sediment transport. Computers \& Geosciences, 89, 207, 2016.
56. MICHALIK A., KSIAZEK L. Dynamics of water flow on degraded sectors of Polish mountain stream channels. Polish Journal of Environmental Studies, 18 (4), $665,2009$.

57. GNATOWSKA R. A study of downwash effects on flow and dispersion processes around buildings in tandem arrangement. Polish Journal of Environmental Studies 24 (4), 2015.

58. VAN DER WEGEN M., JAFFE B.E. Towards a probabilistic assessment of process-based, morphodynamic models. Coastal Engineering, 75, 52, 2013.

59. OLSEN N.R.B. A three dimensional numerical model for simulation of sediments movements in water intakes with multiblock options - Users' Manual. The Norwegian University of Science and Technology. 2014.

60. KITSIKOUDIS V., SIDIROPOULOS E., HRISSANTHOU $\mathrm{V}$. Assessment of sediment transport approaches for sandbed rivers by means of machine learning. Hydrological Sciences Journal, 60 (9), 1566, 2015.

61. KASPEREK R. Changes in the meandering Upper Odra River as a result of flooding Part I. Morphology and biodiversity. Pol. J. Environ. Stud 24, No. 6, 2459, 2015.

62. KHOSRONEJAD A., KANG S.,SOTIROPOULOS F. Experimental and computational investigation of local scour around bridge piers. Advances in Water Resources. 37, 73, 2012.

63. BEHESHTI A.A., ATAIE-ASHTIANI B. Scour hole influence on turbulent flow field around complex bridge piers. Flow, Turbulence and Combustion, 97 (2), 451, 2016.

64. BISCARINI C., DI FRANCESCO S., MANCIOLA P. CFD modelling approach for dam break flow studies. Hydrology and Earth System Sciences, 14 (4), 705, 2010.

65. GHOSH S., PRATIHAR D.K., MAITI B., DAS P.K. An evolutionary optimization of diffuser shapes based on CFD simulations. International journal for numerical methods in fluids, 63 (10), 1147, 2010.

66. HU H., WANG K.H. Modelling flows and sediment concentrations in a sloping channel with a submerged outlet using a hybrid finite-analytic approach. Computers \& Fluids. 44 (1), 9, 2011.

67. TERAGUCHI H., NAKAGAWA H., KAWAIKE K., YASUYUKI B., ZHANG H. Effects of hydraulic structures on river morphological processes. International Journal of Sediment Research. 26 (3), 283, 2011.

68. NOH J., LEE S., KIM J.S., MOLINAS A. Numerical modelling of flow and scouring around a cofferdam. Journal of Hydro-environment Research. 6 (4), 299, 2012.

69. ZHANG H., NAKAGAWA H., KAWAIKE K., YASUYUKI B. Experiment and simulation of turbulent flow in local scour around a spur dyke. International Journal of Sediment Research. 24 (1), 33, 2009. 
